\title{
THE INFLUENCE OF BRAND IMAGES YAMAHA MIO MOTORCYCLE ON CV BURSA MOTOR YAMAHA, KABANJAHE
}

\author{
Ingan Ukur Br Sitepu, Chyty Emmyca Br Bangun \\ Faculty of Ekonomi Quality, Universitas Quality \\ Email: inganukur.sitepu@yahoo.com
}

\begin{abstract}
The image of the Yamaha Mio brand is one of the most important factors because the brand images is very important to sell to prospective consumers, given the competition in the motorcycle business today can be categorized as a battle for the formation and maintenance of product images in the eyes of consumers. The purpose of this research in this thesis is to determine the extent of the influence of brand images on Yamaha Mio's furniture decisions in CV. Kabanjahe Yamaha Motorcycle Exchange. This type of research is quantitative descriptive, data sources used are primary data and secondary data. Data collection techniques are through questionnaires, interviews and observations. The analytical method used is simple linear regression analysis method. The population in this study are consumers who have bought or used Yamaha Mio on CV. Kabanjahe Yamaha Motor Exchange, amounting to 290 people / month. The number of respondents to be sampled is 75 people. The results showed that the independent variables influenced furniture decisions. This is indicated by the results of partial testing of the calculated t value of the brand images variable (X) of 11.284 greater than the $t$ table of 1.982. Adjust R Square of 0.636 which means that the variable brand images has the ability to explain the Yamaha Mio purchase decision on the CV. The Kabanjahe Yamaha Motor Exchange was $63.6 \%$ while the remaining $46.4 \%$ was by other factors not examined in this study. The conclusion of this research is that brand images influences the purchase decision of Yamaha Mio on CV. Kabanjahe Yamaha Motorcycle Exchange.
\end{abstract}

Keywords: Brand Image, Purchase Decision.

Received 26 January 2020 Accepted 20 December 2020

\section{INTRODUCTION}

Increasing competition in the business world almost occurs in all industries and services including the automotive industry. So that producers in this industry compete so that the products produced are accepted by consumers and even successful in the market. Consumers in buying a product do not just buy it right away but they first identify what they need, especially for two-wheeled vehicle products. Consumers must be really selective in deciding which vehicle to buy.

Nowadays a lot of motorcycle brands have sprung up with various models, designs, providing good quality and competitive prices. This is shown in the increasingly widespread business with spectacular developments, for companies engaged in the automotive sector this is an opportunity to dominate the market share. 


\section{THEORETICAL}

\section{Definition of Brand}

The brand is a symbol and indicator of the quality of a product. Product brands that have long been known by consumers have become an image and even a status symbol for the product. So it is not surprising if brand images is used as a criterion in evaluating a product.

\section{Definition of Brand Image}

Brands can foster an image of a company. The thing to consider is to maintain and enhance a brand image that is positive. Therefore it is very important for a company to grow the brand image of its product or company. Aaker (in Alma, 2011: 148) says: "The image will be formed within a certain time period because this is an accumulation of perception of an object, it is known that experienced is entered into one's memory based on inputs from various sources all the time".

\section{Understanding Purchase Decisions}

Consumer behavior is centered on the characteristics of individuals making decisions to utilize their available resources such as time, money and effort to obtain goods related to consumption. According to Schiffman and Kanuk (2008: 485): "The decision is the selection of two or more alternative choices. In other words, alternative choices must be available to someone when making a decision. If someone has a choice between making a purchase and not making a purchase, a choice between brand $\mathrm{X}$ and brand $\mathrm{Y}$, or the choice to spend time working on A or B that person is in a position to make a decision. Conversely, if the consumer has no alternative to choose and is really forced to make certain purchases or take certain actions.

\section{POPULATION AND RESEARCH SAMPLES}

\section{Population}

According to Sugiyono (2009: 115): "Population is the area of generalization consisting of: objects / subjects which have the quantity and characteristics of course determined by researchers to study and draw conclusions". In this study the population was 290 people.

\section{Sampels}

In a large population it is not possible to have everything served as a sample because it will require enormous costs, time and energy. To avoid this, a sample taken from this population is needed. According to Sugiyono (2009: 116): "The sample is part of the number and characteristics of the population. If the population is large, and research studies everything in the population, for example due to limited funds, manpower and time, then researchers cannot use samples taken from that population"

The research sample is part of the population that is expected to represent the characteristics of the entire population. In this study the number of samples is determined by the Slovin formula, namely:

$\mathrm{n}=290$

$$
1+290(0.1) 2
$$

$\mathrm{n}=290$

$$
1+2.9
$$

$\mathrm{n}=74,35897 / 75$ people

Information:

$\mathrm{n}=$ Number of samples 
$\mathrm{N}=$ population size

$\mathrm{e}=$ Percentage of inaccuracy due to sample errors that can still be tolerated $10 \%$

\section{DATA ANALYSIS TECHNIQUES}

The analytical method used to analyze the data collected is as follows:

a. Descriptive analysis is an analysis conducted to determine the value of variables, for example to answer the question of how consumers' decisions on purchasing Yamaha Mio motorcycles on the CV. Kabanjahe Yamaha Motorcycle Exchange.

b. Quantitative analysis is the analysis used to present data in the form of numbers. The test tool used to analyze the hypotheses in this study is to use simple linear regression analysis to test the independent variables of brand image against the dependent variable on purchasing decisions of Yamaha Mio motorcycles.

\section{Test Validity}

Trihendrari (2013: 273) explains that: "The validity test shows whether the questionnaire is able to measure what must be measured. Intended to measure whether or not a valid questionnaire will be distributed to respondents who are sampled in research"

Valid or valid instruments have high validity while less valid instruments have low validity. Each instrument that is declared valid or not is measured through the calculated $r$ value and $r$ the assessment criteria table as mentioned.

Sugiyono (2010: 127) who knows:

"a. If $\mathrm{r}$ arithmetic> from $\mathrm{r}$ critical (0.6), then the questionnaire items are valid

b. If $\mathrm{r}$ arithmetic < from critical $\mathrm{r}(0.6)$, then the questionnaire items are invalid" Validity test is carried out with the help of SPSS program version 21.0.

\section{Reliability Test}

In processing data it certainly gets value from that processing. In reliability testing every value of the data processed must be the same when the data is processed repeatedly.

Trihendradi (2013: 277) explains that: "The questionnaire instrument must be reliable. Reliable means that the instrument produces a consistent measure when used to measure repeatedly, the questionnaire instrument is declared to be reliable if it has a Cronbach's alpha value> 0.6 ". Reliability testing was carried out with the help of the SPSS software program version 21.0. The above understanding explains that each value generated from data processing results must have a stable value when the data processing is repeated.

\section{Normality test}

Normality test is done to see whether in the regression model the independent and dependent variables have normal distribution data or not.

Sangadji and Sopiah (2010: 233) explain that: "Measurement data in table form is used to find out whether it is included in the curve shape, normal distribution or not. With these findings, the researcher can determine his statistical analysis using parametric or nonparametric statistics" All stages of normality testing will be made easier by using the SPSS version 21.0 application. 
Simple Linear Regression Analysis

A simple linear regression analysis was carried out to obtain the relationship of the independent variable $\mathrm{X}$, namely the Yamaha Mio motorcycle brand image with the dependent variable or variable Y, namely the purchasing decision in the CV. Kabanjahe Yamaha Motorcycle Exchange. To analyze the relationship of variable $\mathrm{X}$ to variable $\mathrm{Y}$ whether it is linear or not, the authors conducted a simple regression analysis with the equation of the regression equation $\mathrm{Y}=\mathrm{a}+\mathrm{bx}$ (Arikunto, 2009: 372), where:

$\mathrm{Y}=$ predicted value

$\mathrm{X}=$ predictor variable value

$\mathrm{b}=$ predictor coefficient number

$\mathrm{a}=$ constant number

$\mathrm{e}=$ error

\section{Statistical Test $t$ (Partial Test)}

$\mathrm{T}$ test aims to see the effect of independent variables, namely the influence of brand image on purchasing decisions Yamaha Mio on CV. Kabanjahe Yamaha Motorcycle Exchange. The partial hypothesis testing criteria are as follows:

$\mathrm{H} 0=0$. This means that the brand image does not affect the purchasing decision of Yamaha Mio

Ha $\neq 0$. This means that the brand image influences the decision to purchase a Yamaha Mio motorcycle.

$\mathrm{T}$ calculated value will be compared with t table. The decision making criteria for this statistical test are as follows:

Ho is accepted if $\mathrm{t}$ arithmetic $<\mathrm{t}$ table, at $\alpha=5 \%$

$\mathrm{Ha}$ is accepted if $\mathrm{t}$ arithmetic $>\mathrm{T}$ table, at $\alpha=5 \%$.

\section{RESULTS AND DISCUSSION}

\section{Descriptive Analysis of Respondents}

Descriptive analysis in this study is a description or explanation of the results of primary data collection in the form of a questionnaire that was filled out by research respondents. The number of samples in this study were 75 respondents.

Simple Linear Regression Analysis

Simple linear regression analysis is the relationship between the independent variable $(\mathrm{X})$ that is the brand image with the dependent variable (Y), namely the purchasing decision on the CV. Kabanjahe Yamaha Motorcycle Exchange. With the provisions of the hypothesis as follows:

1. Ho: there is no significant influence between brand image and purchasing decisions

2. Ha: there is a significant influence between brand image and purchasing decisions

If sig> 0.05 then Ho is accepted, sig <0.05 then Ho is rejected.

Based on the results of data processing SPSS ver 21, the following results are obtained:

Table 1. Simple Linear Regression Analysis Results Coefficients

\begin{tabular}{|c|c|c|c|c|c|}
\hline & \multicolumn{2}{|c|}{ Unstandardized Coefficients } & \multirow{2}{*}{$\begin{array}{c}\begin{array}{c}\text { Standardized } \\
\text { Coefficients }\end{array} \\
\text { Beta } \\
\end{array}$} & \multirow[t]{2}{*}{$\mathrm{T}$} \\
\hline \multicolumn{2}{|c|}{ Model } & $\mathrm{B}$ & Std. Error & & \\
\hline \multirow{2}{*}{1} & (Constant) & 2,824 & 1,316 & & 2,145 \\
\hline & TX & ,840 & ,074 & ,797 & 11,284 \\
\hline
\end{tabular}

sumber : Data diolah SPSS ver.21, 2015 
Based on Table 1, a simple linear regression equation can be formulated, namely:

$\mathrm{Y}=2.824+0.840 \mathrm{X}$

The form of the regression equation above has the following meanings:

1. Constants $=2,824$

This constant value gives the sense that if the independent variable (brand image) is zero then the purchase decision is worth 2,824.

2. Regression coefficient X (brand image) $=0.840$

This coefficient gives the sense that if there is an increase in one unit of brand image will be followed by an increase in purchasing decisions by 0.840 units.

Partial Test ( $t$ test)

$\mathrm{T}$ test was conducted to determine the effect of each or partially the independent variable (brand image) on the dependent variable (purchase decision). Tcount value will be compared with ttable. Decision making criteria for this statistical test are as follows:

Table 2. Simple Linear Regression Analysis Results Coefficients

\begin{tabular}{|c|c|c|c|c|c|}
\hline \multicolumn{2}{|c|}{ Model } & \multicolumn{2}{|c|}{ Unstandardized Coefficients } & \multirow{2}{*}{$\begin{array}{c}\begin{array}{c}\text { Standardized } \\
\text { Coefficients }\end{array} \\
\text { Beta }\end{array}$} & \multirow[t]{2}{*}{$\mathrm{T}$} \\
\hline & & B & Std. Error & & \\
\hline \multirow{2}{*}{1} & (Constant) & 2,824 & 1,316 & & 2,145 \\
\hline & TX & 840 & ,074 & ,797 & 11,284 \\
\hline
\end{tabular}

Sumber : Data diolah SPSS ver.21, 2015

Based on Table 2, a simple linear regression equation can be formulated, namely:

$\mathrm{Y}=2.824+0.840 \mathrm{X}$

The form of the regression equation above has the following meanings:

1. Constants $=2,824$

This constant value gives the sense that if the independent variable (brand image) is zero then the purchase decision is worth 2,824.

2. Regression coefficient $X$ (brand image) $=0.840$

This coefficient gives the sense that if there is an increase in one unit of brand image will be followed by an increase in purchasing decisions by 0.840 units.

Partial Test ( $t$ test)

$\mathrm{T}$ test was conducted to determine the effect of each or partially the independent variable (brand image) on the dependent variable (purchase decision). Tcount value will be compared with $t$ table. Decision making criteria for this statistical test are as follows:

Table 3. Test Results t Coefficients ${ }^{\mathrm{a}}$

\begin{tabular}{|c|c|c|c|c|c|c|}
\hline & \multicolumn{2}{|c|}{ Unstandardized Coefficients } & \multirow{2}{*}{$\begin{array}{c}\begin{array}{c}\text { Standardized } \\
\text { Coefficients }\end{array} \\
\text { Beta } \\
\end{array}$} & \multirow[t]{2}{*}{$\mathrm{T}$} & \multirow[t]{2}{*}{ Sig. } \\
\hline \multicolumn{2}{|c|}{ Model } & $\mathrm{B}$ & Std. Error & & & \\
\hline \multirow{2}{*}{1} & (Constant) & 2,824 & 1,316 & & 2,145 &, 035 \\
\hline & $\mathrm{TX}$ &, 840 & ,074 & ,797 & 11,284 &, 000 \\
\hline
\end{tabular}

a. Dependent Variable: TY

Sumber :Data diolah SPSS ver.21,2015 
From Table 3 above, it can be seen the results of the regression analysis obtained coefficients for brand image variables of 0.840 with a constant of 2.824 so that the regression equation model obtained is as follows:

$\mathrm{Y}=2.824+0.840 \mathrm{X}$

The results of the analysis using SPSS version 21.0 were obtained as follows: Effect of Brand Image on Purchasing Decisions for Yamaha Mio. Empirical test results of the influence between brand image on purchasing decisions of Yamaha Mio showed a t value of 11.284 and (Sig) of 0.000 which is below alpha 5\%. This means that the brand image influences the purchasing decision of Yamaha Mio. The results of the study cannot reject the hypothesis which states "there is a significant effect between brand image variables on Yamaha Mio purchasing decisions". Beta value in Understandardized Coefficents of brand image variable shows a coefficient figure of 0.840 which means that every 1 increase in brand image variable will add to the decision of purchasing a Yamaha Mio motorcycle by 0.840 .

Regression coefficient of 2.824 means that if the brand image $(\mathrm{X})$ is zero then the purchase decision (Y) is positive at 2.824. In other words, without the brand image, the magnitude of the purchase decision is 2.824 .

Determination Test (R2)

The determination test aims to find out the percentage of variation in the dependent variable that can be explained by the variance in the independent variables looking for the value of R2.

Table 4. Determination Coefficient Analysis Test Results Model Summary ${ }^{\mathrm{b}}$

\begin{tabular}{|c|c|c|c|c|c|c|c|c|c|}
\hline \multirow[t]{2}{*}{ Model } & \multirow[t]{2}{*}{$\mathrm{R}$} & \multirow[t]{2}{*}{ R Square } & \multirow{2}{*}{$\begin{array}{c}\text { Adjusted R } \\
\text { Square }\end{array}$} & \multirow{2}{*}{$\begin{array}{l}\text { Std. Error of the } \\
\text { Estimate }\end{array}$} & \multicolumn{5}{|c|}{ Change Statistics } \\
\hline & & & & & $\begin{array}{c}\text { R Square } \\
\text { Change }\end{array}$ & F Change & df1 & df2 & $\begin{array}{c}\text { Sig. F } \\
\text { Change }\end{array}$ \\
\hline 1 &, $797^{\mathrm{a}}$ & ,636 & ,631 & 1,85089 & 636 & 127,331 & 1 & 73 & ,000 \\
\hline
\end{tabular}

a. Predictors: (Constant), citra merk

b. Dependent Variable: keputusan pembelian

Sumber : Data diolah SPSS ver.21, 2019

From Table 4. above, the calculation results obtained an R2 value of 0.636 . This coefficient indicates that $63.6 \%$ of the changes that occur in purchasing decisions are influenced by brand image variables while the remaining $36.4 \%$ are influenced by other variables not examined.

\section{Discussion}

This study found the coefficient of determination in table 4 . of 0.636 which showed that the brand image variable explained $63.6 \%$ of the change from the purchase decision variable while the remaining $36.4 \%$ was explained by other factors not examined.

From the results of tests carried out it is proven that the brand image has a significant influence on purchasing decisions of Yamaha Mio on CV. Kabanjahe Yamaha Motorcycle Exchange. With a significance level of 0,000 and a $t$ value of 11.284. This indicates that the higher the influence of brand image, it can increase the purchasing decision of Yamaha Mio on CV. Kabanjahe Yamaha Motorcycle Exchange. Brand image is a factor that is taken into account in product sales to maintain the stability of consumer purchasing decisions. Thus it can be concluded that based on testing of 75 respondents are users of Yamaha Mio products recorded in the CV. Kabanjahe 
Yamaha Motor Exchange accepts Ha that there is a significant influence between the variable brand image on purchasing decisions of Yamaha mio motorcycles.

This research is in accordance with the theory put forward by Kotler (2008: 32) "Brand image as a set of beliefs, ideas and impressions possessed by someone towards a brand". The results of the research that the author did showed that the citramerk has a significant influence on motorcycle purchasing decisions Yamaha Mio.

From the discussion above that the brand image $(\mathrm{X})$ to the purchase decision $(\mathrm{Y})$ has a significant influence, namely through the responses of respondents are as follows: Brand image shows that most respondents gave a high response to the brand image of Yamaha Mio. This is demonstrated by the availability of the largest spare parts in the automotive industry, extensive sales network, consumers feel confident using Yamaha Mio, unique designs and a variety of color choices and Yamaha Mio is a quality product and has high engine durability.

\section{CONCLUSIONS AND SUGGESTIONS}

\section{Conclusions}

Based on the analysis and evaluation discussed in the thesis, the following conclusions can be drawn:

1. From the correlation coefficient of 0.636 , the magnitude of the contribution of the brand image to the purchase decision of $63.6 \%$ with the remaining $36.4 \%$ influenced by other factors outside this study.

2. The validity test is carried out on 10 items of questions submitted valid because $r$ count is greater than $r$ table. While based on the reliability test, the value of Cronbach's alpha was 0.715 for the brand image variable and 0.722 for the purchase decision variable so the questions asked to respondents were reliable.

3. Regression equation between brand image and purchase decision obtained $\mathrm{Y}=2.824+0.840 \mathrm{X}$. This means that the brand image variable influences the purchasing decision of 2.824 .

\section{Suggestions}

Based on the conclusions there will be raised some suggestions that would be necessary. Suggestions that can be given are as follows:

1. So that the Yamaha brand image can support its marketing activities, CV. Kabanjahe Yamaha Motor Exchange can improve its image even better.

2. CV. Kabanjahe Yamaha Motor Exchange should be more open to criticism or consumer complaints so they can find out things that are still not good and can be taken to improve it.

3. It is better CV. Kabanjahe Yamaha Motorcycle Exchange is giving salespeople a stimulus so they want to market more Yamaha Mio motorcycles. For example by giving the number of discounts given to consumers so that they make a profit by giving a bonus at the end of the year.

4. CV. BursaMotor Yamaha Kabanjahe should provide guidance and direction by providing greater incentives to encourage / increase the motivation of sales in marketing Yamaha Mio. 
5. For the next writer, it is expected to examine the variables outside the variables that have been studied in order to obtain more varied results that can affect the purchasing decision of Yamaha Mio motorcycles on the CV. Kabanjahe Yamaha Motorcycle Exchange.

6. It is recommended that companies improve the image formed for consumers in choosing Yamaha motorcycles, for example by providing awareness to consumers or finding out consumers' expectations of Yamaha products.

\section{REFERENCES}

[1] Alma, Buchari. 2011. Manajemen Pemasaran dan Pemasaran Jasa. Cetakan Kesembilan. Bandung: Alfabeta.

[2] Arikunto, Suharsimi. Manajemen Penelitian. 2009. Jakarta: PT Rineka Cipta

[3] Dedy Yanto. 2008. Pengaruh Brand Image terhadap Pengambilan Keputusan Pembelian Sepeda Motor Honda Beat pada Cendrawasih Motor di Medan. Medan: Skripsi.

[4] Ferrinadewi, Erna. 2008. Merek dan Psikologi Konsumen. Yogyakarta: Graha Ilmu.

[5] Hartimbul, F Nembah.2011. Manajemen Pemasaran Cetakan I. Bandung: Yrama Widya.

[6] Hasan,Ali. 2010. Marketing dan Kasus- kasus Pilihan. Yogyakarta: CAPS.

[7] Herlambang, Susatyo. 2014. Basic Marketing (Dasar-dasar Pemasaran) Cara Mudah Memahami Ilmu Pemasaran. Yogyakarta: Gosyen Publishing.

[8] Kotler, Philip, Keller. 2009. Manajemen Pemasaran. Jakarta: Erlangga.

[9] Mamang Sangadi, Etta dan Sopiah. 2013. Perilaku Konsumenedisi 1.Yogyakarta: Andi Offset.

[10] Sunyoto, Danang. 2012. Dasar-dasar Manajemen Pemasaran Konsep, Strategi dan Kasus. Cetakan Pertama. Yogyakarta: CAPS.

[11] Surachman. 2008. Dasar-dasar Manajemen Merek Alat Pemasaran untuk Memenangkan Persaingan. Malang: Bayumedia Publishing.

[12] Schiffman, Leon,Kanuk. Perilaku Konsumen. Bandung:PT.Macanan Jaya Cemerlang.

[13] Setiadi, J Nugroho. 2013. Perilaku Konsumen edisi revisi Cetakan keempat. Jakarta: Kencana.

[14] Sugioyono.2009. Metode Penelitian Kuantitatif Kualitatif dan $R \& D$ cetakan ke delapan. Bandung: Alfabeta .

[15] Trihendradi, C. 2013. Step By Step IBM SPSS 21; Analisis Data Statistik. Yogyakarta: Andi Offset

[16] Nurul Huda. 2012. Pengaruh Brand Image Terhadap Keputusan Pembelian Motor Scuter Matic Yamaha di Medan. Medan: Skripsi

[17] Tjiptono, Fandy. Manajemen dan Strategi Merek. 2011. Yogyakarta: Andi. 